\begin{tabular}{|l|l|l|}
\hline \multicolumn{2}{|c|}{ PublisherInfo } \\
\hline \hline PublisherName & $:$ & BioMed Central \\
\hline \hline PublisherLocation & $:$ & London \\
\hline \hline PublisherImprintName & $:$ & BioMed Central \\
\hline \hline
\end{tabular}

\title{
A new concept for Urate in human serum: Evidences that support the existence of Urate as loosely associated and protein-bound Urate in human serum
}

\begin{tabular}{|l|l|l||}
\hline \multicolumn{2}{|c|}{ ArticleInfo } \\
\hline \hline ArticleID & $:$ & 312 \\
\hline \hline ArticleDOI & $:$ & $10.1186 /$ ar312 \\
\hline \hline ArticleCitationID & $:$ & E002 \\
\hline \hline ArticleSequenceNumber & $:$ & 14 \\
\hline \hline ArticleCategory & $:$ & Non-peer-reviewed research \\
\hline ArticleFirstPage & $:$ & 1 \\
\hline \hline ArticleLastPage & $:$ & 10 \\
\hline \hline & & RegistrationDate : 2001-4-25 \\
\hline ArticleHistory & $:$ & OnlineDate \\
\hline ArticleCopyright & $:$ & BioMed Central Ltd2001-4-25 \\
\hline \hline ArticleGrants & $:$ & \\
\hline \hline ArticleContext & $:$ & 130753344 \\
\hline \hline
\end{tabular}


Ahmed Nabil Hegazi Ph.D., Aff1

Corresponding Affiliation: Aff1

Email: ahmed_nabil_h@hotmail.com

Aff1 Clinical lab., Ain Shams University Hospitals, Ain Shams University, Egypt

\section{Introduction}

In this paper, it has been experimentally proved for the first time that urate is present in human serum bound to proteins. The protein-bound urates, when liberated, absorb in the ultraviolet light at wavelengths shorter than $293-295 \mathrm{~nm}$, the wavelength at which the pure uric acid solution gives his maximum peak [1] .

Furthermore; the presence of other protein-bound substances which after being free, give rise to an increase in the absorption spectrum in the region between 270 and $300 \mathrm{~nm}$ and not attacked by uricase has been established.

\section{Materials and Reagents}

According to the fact that uric acid has its maximum absorbance in the U.V. light between the W.Ls of $290 \mathrm{~nm}$ and $295 \mathrm{~nm}$ under optimized conditions and making use of the specific destructive effect of uricase on uric acid, the absorption spectrum of a serum sample was carefully studied in the region between $270-300 \mathrm{~nm}$ before and after incubation with uricase.

\section{Reagents}

- Sodium hydroxide solution; 0.1 and $0.4 \mathrm{~mol} / \mathrm{L}$.

- Tris buffer, pH. 8.5, $0.1 \mathrm{~mol} / \mathrm{L}$; Keep at $4^{\circ} \mathrm{C}$.

- Glycine buffer, pH. 9.35, 1.33 mol/L; Dissolve 50 grams of glycine and 8.8 grams of sodium hydroxide in $500 \mathrm{ml}$ of distilled water, warm if necessary. Check the $\mathrm{pH}$. Preserve with few drops of chloroform and keep at $4^{\circ} \mathrm{C}$. 
- Uricase (urate : oxygen oxidoreductase, EC 1.7.3.3), 25 units in $25 \mathrm{ml}$ of $0.1 \mathrm{~mol} / \mathrm{L}$ Tris buffer, pH. 8.5, divide in $0.5 \mathrm{ml}$ aliquots and keep frozen till use.

- Uricase (urate:oxygen oxidoreductase, EC 1.7.3.3),25 unit in $1 \mathrm{ml}$ of $0.1 \mathrm{~mol} / \mathrm{L}$ of glycine buffer pH 9.35, just before use.

- Trichloroacetic acid (TCA) 50 g./L.

- Uric acid standard solution, $5.949 \mathrm{mmol} / \mathrm{L}$.

\section{Experimentals}

\section{Incubation of diluted serum with uricase}

To $6 \mathrm{ml}$ of Tris buffer solution, $0.1 \mathrm{~mol} / \mathrm{L}, \mathrm{pH} .8 .5$, in a test tube add $20 \mathrm{uL}$ of serum and mix. Set up a standard by diluting $10 \mathrm{uL}$ of the standard uric acid solution, $5.945 \mathrm{mmol} / \mathrm{L}$, to a final volume of five $\mathrm{ml}$ with the Tris buffer solution. Record the absorbance in the region between 275 and $300 \mathrm{~nm}$ against the Tris buffer solution as blank. Add 0.1 unit of uricase (reagent 4 ) to each tube and incubate at room temperature $\left(25^{\circ} \mathrm{C}\right)$ for two hours. Record the absorbance again for both the sample tube and the standard against the blank within the same range of wavelengths. Repeat the measurements after 48 hours incubations

\section{Incubation of both the protein-free supernatant and the protein solution separately with uricase}

To $200 \mathrm{uL}$ of serum, add $1.8 \mathrm{ml}$ of $50 \mathrm{~g} / \mathrm{L} \mathrm{TCA}$, mix and centrifuge $(1200 \times \mathrm{g})$ for five minutes. Transfer $1 \mathrm{ml}$ of the clear supernatant to a tube containing $3 \mathrm{ml}$ of $1.33 \mathrm{~mol} / \mathrm{L}$ glycine buffer, $\mathrm{pH} 9.35$, and carry out the optical measurement in the region from 270-300 nm against a blank consists of $1 \mathrm{ml}$ of $50 \mathrm{~g} / \mathrm{L} \mathrm{TCA}$ and $3 \mathrm{ml}$ of the glycine buffer. On the other hand, dissolve the precipitated proteins in $5 \mathrm{ml}$ of $0.1 \mathrm{~mol} / \mathrm{L}$ sodium hydroxide solution, Buffer $1 \mathrm{ml}$ of this solution with $3 \mathrm{ml}$ of glycine buffer, 1.33 $\mathrm{mol} / \mathrm{L}, \mathrm{pH} 9.35$ and carry out the optical measurements in the same way as with the clear protein-free supernatant. After the addition of 0.1 unit of uricase (reagent 4 ) to each of the buffered solutions, record the absorbance as before after incubation at room temperature $\left(25^{\circ} \mathrm{C}\right)$ for two hours, 24 and 72 hours.

\section{Incubation of the protein-free supernatant with uricase after treating the serum sample with sodium}




\section{hydroxide solution $0.4 \mathrm{~mol} / \mathrm{L}$, at $60^{\circ} \mathrm{C}$ fore different periods}

To each of three test tubes containing $200 \mathrm{uL}$ of a serum sample,add $0.8 \mathrm{ml}$ of $0.4 \mathrm{~mol} / \mathrm{L}$ sodium hydroxide solution, mix and leave in water bath $60^{\circ} \mathrm{C}$.

After 5 minutes add $1 \mathrm{ml}$ of $0.2 \mathrm{~mol} / \mathrm{L}$ citric acid, mix and leave for further 1 minutes in the bath. After centrifugation $(1200 \times \mathrm{g})$ transfer $1 \mathrm{ml}$ of the clear supernatant to another tube containing $3 \mathrm{ml}$ of glycine buffer $1.33 \mathrm{~mol} / \mathrm{L} \mathrm{pH} 9.35$ and keep ready for optical measurements.

Repeat this step with the other two test tubes after leaving in the water bath $60^{\circ} \mathrm{C}$ for periods of 10 , and 15 minutes respectively.

Record the U.V spectrum for each of the three tubes in the region between 270 and $300 \mathrm{~nm}$.; Then add 5 units of uricase (reagent 5) to each tube, mix and leave at room temp. $\left(28^{\circ} \mathrm{C}\right)$ for two hours. Record the absorbance again in the same region of W.Ls.

\section{Results}

The results obtained are illustrated in tables 1,2 and figures $1,2,3,4 \& 5$.

Figure 1 Curve (a) represents the difference between the absorbance before and after incubation of the diluted serum sample with uricase for two hours. The max. decrease was recorded at 283-285 nm. Curve (b) represents the difference between the absorbance before and after the action of uricase for two hours on the pure uric acid solution. The max. decease was recorded at $293 \mathrm{~nm}$

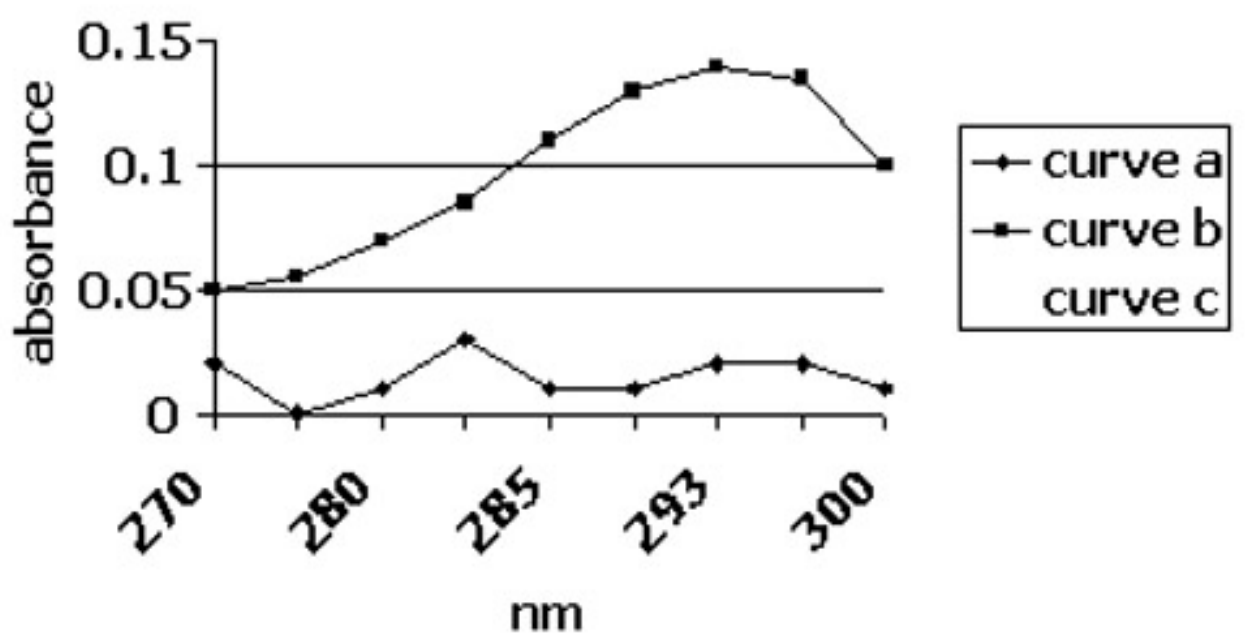


Figure 2 Curve (a) represents the difference between absorbance of the precipitated- protein solution before and after 24 hours incubation with uricase. The max. decrease obtained was at $283 \mathrm{~nm}$. Curve (b) represents the difference between absorbance of the protein-free solution before and after 2 hours incubation with uricase. The max. decrease obtained was at $293 \mathrm{~nm}$.

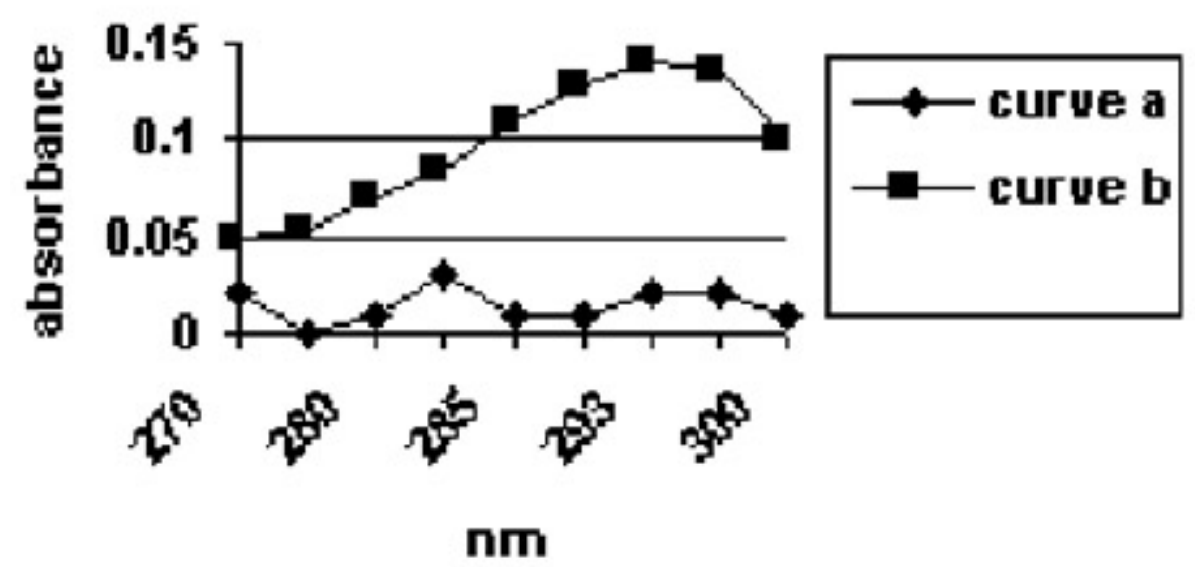

Figure 3 The absorption spectra of the protein-free supernatant after leaving the serum sample for 5 minutes with sodium hydroxide solution $0.4 \mathrm{~mol} / \mathrm{L}$ at $60^{\circ} \mathrm{C}$. (a)- Before destruction with uricase. (b)After destruction with uricase. The maximum decrease in absorbance recorded was at $295 \mathrm{~nm}$, the same W.L at which the free uric acid solution gives its maximum absorption peak.

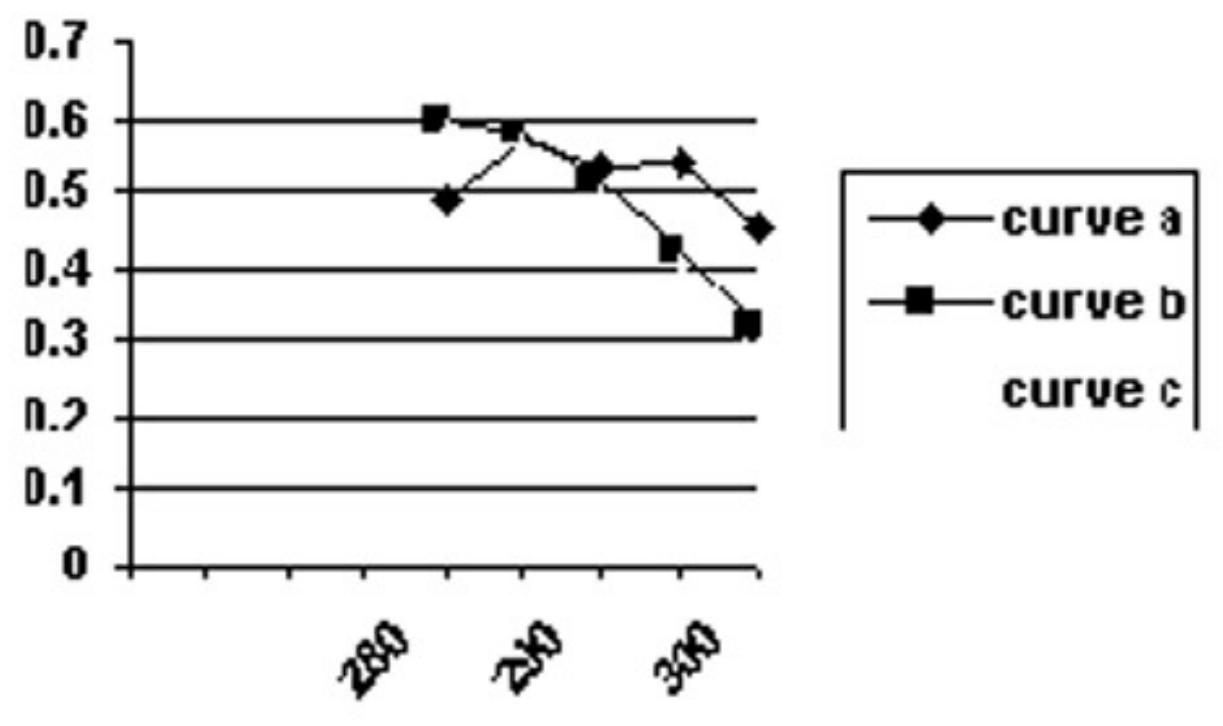


Figure 4 The absorption spectra of the protein-free supernatant after leaving the serum sample for 10 minutes with sodium hydroxide solution $0.4 \mathrm{~mol} / \mathrm{L}$ at $60^{\circ} \mathrm{C}$. (a)-Before destruction with uricase. (b)After destruction with uricase. The maximum decrease in absorbance recorded was at $295 \mathrm{~nm}$, the same W.L at which the free uric acid solution gives its maximum absorption peak. More urate were liberated and absorb in the region between 290-295 nm.

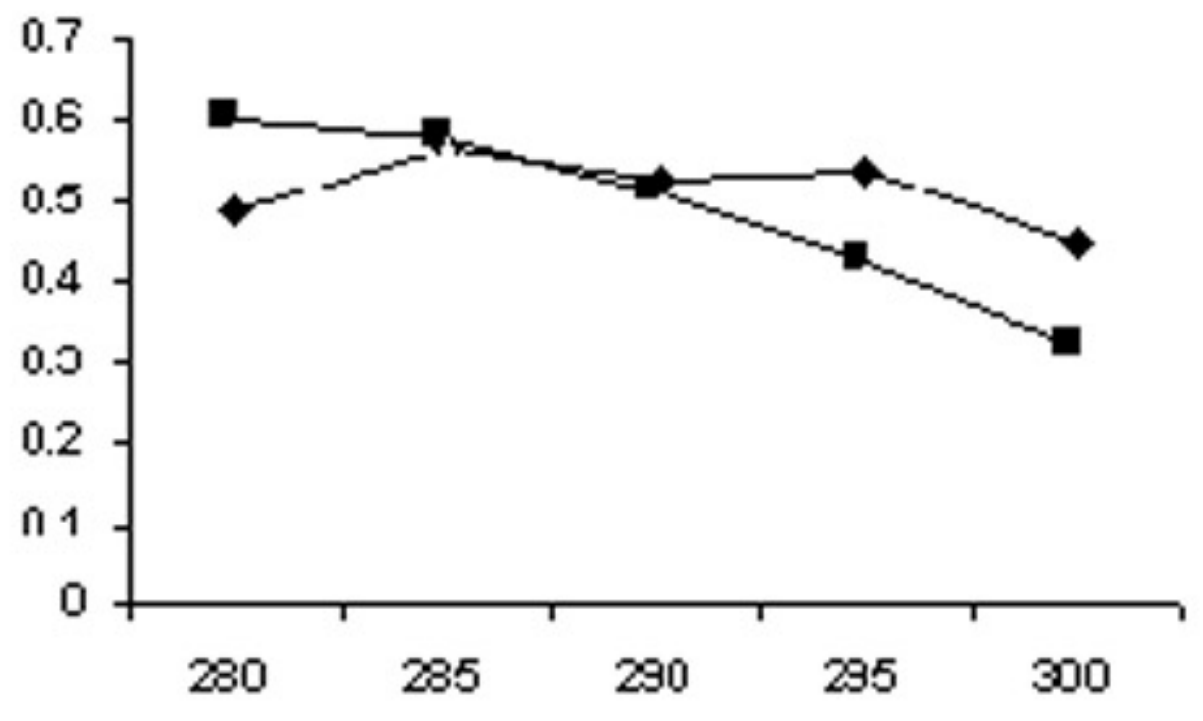

Figure 5 The absorption spectra of the protein-free supernatant after leaving the serum sample for 15 minutes with sodium hydroxide solution $0.4 \mathrm{~mol} / \mathrm{L}$ at $60^{\circ} \mathrm{C}$. (a)-Before destruction with uricase. (b)After destruction with uricase. The maximum decrease in absorbance recorded was at $295 \mathrm{~nm}$, the same W.L at which the free uric acid solution gives its maximum absorption peak. More urate were liberated and absorb in the region between $287-290 \mathrm{~nm}$.

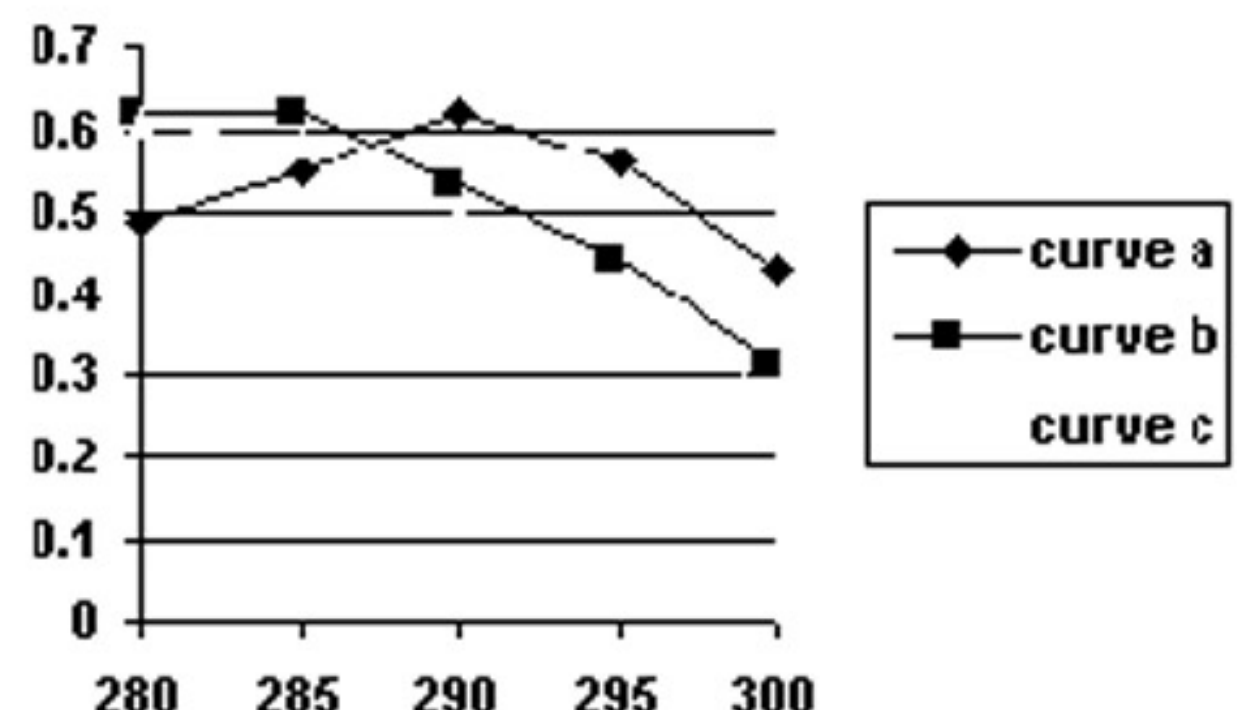


Table 1 The absorption spectra of both the diluted serum sample and the pure uric acid solution before and after the action of uricase

\begin{tabular}{|c|c|c|c|c|c|c|c|}
\hline W.L & \multicolumn{5}{|c|}{ ABSORBANCE } & & \\
\hline $\mathrm{nm}$ & & & & & & & \\
\hline & The serum & & & & The pure uric & & \\
\hline & sample & & & & acid sol. & & \\
\hline & A & B & A-B & C & $\mathrm{U}_{0}$ & $\mathrm{U}_{2}$ & $\mathrm{U}_{0}$ - $_{2}$ \\
\hline 270 & 0.225 & 0.205 & 0.020 & 0.27 & 0.05 & 0.030 & 0.02 \\
\hline 275 & 0.250 & 0.230 & 0.020 & 0.28 & 0.07 & 0.020 & 0.05 \\
\hline 280 & 0.240 & 0.230 & 0.010 & 0.29 & 0.10 & 0.030 & 0.07 \\
\hline 283 & 0.250 & 0.215 & $0.035^{*}$ & 0.30 & 0.130 & 0.030 & 0.10 \\
\hline 285 & 0.255 & 0.220 & $0.035^{*}$ & 0.29 & 0.150 & 0.030 & 0.12 \\
\hline 290 & 0.250 & 0.220 & 0.030 & 0.25 & 0.180 & 0.030 & 0.15 \\
\hline 293 & 0.220 & 0.205 & 0.015 & 0.165 & 0.190 & 0.030 & $0.16^{*}$ \\
\hline 295 & 0.160 & 0.155 & 0.005 & 0.150 & 0.180 & 0.030 & 0.15 \\
\hline 300 & 0.110 & 0.110 & 0.000 & 0.110 & 0.170 & 0.030 & 0.14 \\
\hline
\end{tabular}

The serum sample: A : The absorbance before the addition of uricase. B : The absorbance after 2 hours incubation with uricase. A-B : The difference between absorbances before and after incubation for 2 hours with uricase, the max. decrease is at 283-285 nm. C : The absorbance after 48 hours incubation with uricase, the abosrbance recorded was higher than that recorded before the action of uricase over the whole region of measurement $(270-300 \mathrm{~nm})$. The pure uric acid solution: $\mathrm{U}_{0}$ : The absorbance before the addition of uricase. $U_{2}$ : The absorbance two hours after the action of uricase. $\mathrm{U}_{0}-\mathrm{U}_{2}$ : The difference between absorbance before and after two hours incubation with uricase, the max. decrease is at $293 \mathrm{~nm}$.

Table 2 The absorption spectra of both the precipitated protein solution and the protein-free supernatant before and after the action of uricase

\begin{tabular}{|c|c|c|c|c|c|c|c|}
\hline W.L & \multicolumn{6}{|c|}{ ABSORBANCE } & \\
\hline \multicolumn{8}{|l|}{$\mathrm{nm}$} \\
\hline & The precipitated & & & & & The protein-free & \\
\hline & protein solution & & & & & supernatant. & \\
\hline & $\mathrm{B}_{0}$ & $\mathrm{~B}_{24}$ & $\mathrm{~B}_{0-24}$ & B72 & $\mathrm{A}_{0}$ & $\mathrm{~A}_{2}$ & $\mathrm{~A}_{0}-\mathrm{A}_{2}$ \\
\hline 270 & 0.620 & 0.600 & 0.020 & 0.63 & 0.210 & 0.160 & 0.050 \\
\hline 275 & 0.620 & 0.620 & 0.000 & 0.64 & 0.210 & 0.155 & 0.055 \\
\hline
\end{tabular}




\begin{tabular}{|c|c|c|c|c|c|c|c|}
\hline 280 & 0.610 & 0.600 & 0.010 & 0.65 & 0.220 & 0.150 & 0.070 \\
\hline 283 & 0.600 & 0.570 & $0.030^{*}$ & 0.65 & 0.230 & 0.145 & 0.085 \\
\hline 285 & 0.580 & 0.570 & 0.010 & 0.63 & 0.250 & 0.140 & 0.110 \\
\hline 290 & 0.520 & 0.510 & 0.010 & 0.55 & 0.270 & 0.140 & 0.130 \\
\hline 293 & 0.480 & 0.470 & 0.020 & 0.52 & 0.280 & 0.140 & $0.140^{*}$ \\
\hline 295 & 0.400 & 0.380 & 0.020 & 0.42 & 0.270 & 0.135 & 0.135 \\
\hline 300 & 0.300 & 0.290 & 0.010 & 0.40 & 0.230 & 0.130 & 0.100 \\
\hline
\end{tabular}

The precipitated-protein soution: $\mathrm{B}_{0}$ : The asorbance before the addition of uricase. $\mathrm{B}_{24}$ : The absorbance after 24 hours incubation with uricase. $\mathrm{B}_{0}-\mathrm{B}_{24}$ : The decrease in the absorbance after incubation for 24 hours with uricase, the max. decrease is at $283 \mathrm{~nm}$. B 72 : The absorbance after 72 hours incubation with uricase, the absorbance recorded was higher than that recorded before the action of uricase over the whole region of measurement $(270-300 \mathrm{~nm})$. The protein -free supernatant : $\mathrm{A}_{0}$ : The absorbance before the addition of uricase. $\mathrm{A}_{2}$ : The absorbance two hours after the action of uricase. $\mathrm{A}_{0}-\mathrm{A}_{2}$ : The difference between absorbance before and after two hours incubation with uricase, the max. decrease reached at $293 \mathrm{~nm}$.

Table 1 (a,b) \& figure 1-curve a; denote a maximum decrease in absorbance at 283-290 $\mathrm{nm}$ after the action of uricase on the buffered diluted serum. On the other hand, the strongest band recorded for the pure uric acid solution was at $293 \mathrm{~nm}$, table $\left.1\left\{\mathrm{U}_{0}-\mathrm{U}_{2}\right)\right\}$ \& figure 1 curve-b; the same wave length at which urate in the buffered protein-free clear supernatant also gives its maximum peak., Table 2 ( $\mathrm{A}_{0}$ A2.), figure $2 b$.

In addition, table $2, \mathrm{~B}_{0}-\mathrm{B}_{24}$, \& figure $2 \mathrm{a}$; show a maximum decrease in absorbance at $283-285 \mathrm{~nm}$ when the buffered protein solution was left under the action of uricase for 24 hours.

After longer incubation periods, 48 hours, table 1, C \& table 2, B72, the recorded absorbance was higher than the original values obtained before the action of uricase, table $1, \mathrm{~A} \&$ table, $\mathrm{B}_{0}$.

The absorption spectra of the clear protein-free supernatant after subjecting the serum for the action of sodium hydroxide solution $0.4 \mathrm{~mol} / \mathrm{L}$ at $60^{\circ} \mathrm{C}$ for 5,10 and 15 minutes, before and after destruction with uricase, as presented in figures 3,4 and 5 showed maximum decrease in absorbace at $295 \mathrm{~nm}$ - the same W.L at which the free uric acid gives its maximum absorption peak -, along the experiment periods of time (5,10 \& 15 minutes),

Moreover, after 15 minutes, more urate were liberated and absorb at $290 \mathrm{~nm}$ - figure 5 .

\section{Discussion}

The results showed a remarkable difference in the wave lengths (W.Ls) at which urate in serum gives its maximum absorbance, $283-290 \mathrm{~nm}$, compared to $293 \mathrm{~nm}$, the W.L. at which the pure uric acid solution gives its maximum band. 
This, could be attributed to the presence of a sort of co-ordination between serum urates and proteins under physiologic conditions. As soon as the proteins were precipitated, part of the serum urates were identified in the protein-free supernatant at the same wavelength at which the free uric acid solution has its maximum peak. This part of serum urate is easily attacked by uricase.

The other part of serum urate appeared to be relatively strongly bound to proteins and is hardly attacked by uricase. After being free, it absorbs at shorter W.Ls, 283-285 nm (experiment [2]).

This might be understood on the basis of the old suggestion of gudzent [2] that both the lactam (keto) and the lactim (enol) toutomers of uric acid might be stable enough to coexist in biological fluids under certain circumstances.

In serum, these forms are expected to co-ordinate with proteins through hydrogen bonding. The energy of the hydrogen bond varies from $8.37 \mathrm{~kJ}$ for the H-N...H to $29.29 \mathrm{~kJ}$ for the H-O...H [3]. Therefore, it appears that the lactim toutomer will be relatively more strongly bound to proteins. Since the hydrogen bond by itself is a weak bond, this can explain why the loosely associated urate (lactam) is easily liberated as soon as the folded (quaternary) structure of proteins was disturbed. However the existence of protein-bound urate (PBU) could not be simply explained on the basis of hydrogen bond formation between the lactim toutomer of urate and proteins. Other type of co-ordinations might be involve to give that relatively stable protein-bound substance (PBU).

On the other hand, the hydrogen bond formation causes a relatively large amount of polarity in serum urate as compared to the pure uric acid solution. This may explain the spectral shifts in the absorbance maximum (283-290 nm) of serum urate compared to 293, $295 \mathrm{~nm}$ for the pure uric acid solution at the same $\mathrm{pH}(8.5,9.35)$. Also this may explain the relative shift in the absorbance of the more polar lactim (PBU) to shorter W.Ls as compared to the relatively less polar lactam.

In addition, further investigation of the absorption spectra of serum between $270 \mathrm{~nm}$ and $300 \mathrm{~nm}$ before and after destruction with uricase demonstrate the presence of protein-bound substances which give their absorption spectra, after liberation from proteins, in the UV light at the W.Ls characteristic to uric acid or urate in serum and not affected by uricase. The rates of liberation of these substances differ than the rate of destruction of uric acid by uricase.

This represents the major obstacle against any attempt to record the real decrease in absorbance at 283-285 nm when serum proteins or the serum were subjected for the action of uricase. Actually, the results obtained are the difference between decrease in uric acid due to the destructive action of uricase and the increase of these liberated substances from proteins .

At the beginning, the rate of destruction of uric acid is higher than the rate of liberation of these substances, the result is a decrease in absorbance at $283-285 \mathrm{~nm}$, the W.L. characteristic for urate max. absorbance in serum.

By the time the rate of liberation of these substances is increased in relation to the destruction rate of urate, this gives rise to increase in absorbance not only at the specific W.L characteristic to urate max. absorbance in serum, but also in the region from 270-300 nm.

Obviously, these substances will interfere with determination of serum urate if the measurements were carried out in the ultraviolet light after destruction with uricase.

At shorter U.V W.Ls, the blank is too high to record any change. 


\section{References}

1. Praetorius E, Poulsen H: Enzymatic determination of uric acid with detailed directions. Scand. J. Clin. \& Lab. Inves . 1953, 5: 273-280.

2. Gudzent : Quantitative Clinical Chemistry, (Peters, J. P., and Van Slyke, D.D., Ed.) vol. Williams's Wilkins Company, Baltimore, and I table. 1946, 24: 635-

3. Finar IL: Organic Chemistry, volume I, The English Language Book. Society and Longman group Limited,. 1973, 40- 